\title{
STABILIZATION OF COMPACTIBLE WASTE
}

E.M. Franz, J.H. Heiser III, and P. Colombo

September 1990

RADIOLOGICAL SCIENCES DIVISION

DEPARTMENT OF NUCLEAR ENERGY

BROOKHAVEN NATIONAL LABORATORY, ASSOCIATED UNIVERSITIES. INC. UPTON, NEW YORK 11973

Prepared for the

NATIONAL LOW-LEVEL WASTE MANAGEMENT PROGRAM

UNITED STATES DEPARTMENT OF ENERGY 


\section{DISCLAIMER}

This report was prepared as an account of work sponsored by an agency of the United States Government. Neither the United States Government nor any agency thereof. nor any of their employees, nor any of their contractors, subcontractors, or their employees, makes any warranty, expres or implied, or assumes any legal liability or responsibility for the accuracy, completeness, or usefulness of any information. apparatus, product. or process disclosed, or represents that its use would not infringe privately owned rights. Reference herein to any specific commercial product, process. or service by trade name, trademark, manufacturer, or otherwise, does not necessarily constitute or imply its endorsement, recommendation, or favoring by the United States Government or any agency, contractor or subcontractor thereof. The views and opinions of authors expressed herein do not necessarily state or reflect thowe of the United States Government or any agency, contractor or subcontractor thereof.

Printed in the United States of America Available from

National Technical Information Service

U.S. Department of Commerce

5285 Port Royal Road

Springfield, VA 22161

NTIS price codes:

Printed Copy: A03; Microfiche Copy: A01 


\section{SUMMARY}

This repert summarizes the results of a series of experiments performed to determine the feasibility of stabilizing compacted or compactible waste with polymers. The need $[1,2]$ for this work arose from problems encountered at disposal sites attributed to the instability of this waste in disposal. These studies are part of an experimental program conducted at Brookhaven National īaboratory (BNL) investigating methods for the improved solidification/stabilization of DOE low-level wastes. Other types of waste streams of concern for which solidification/stabilization studies are being conducted at BNL include concentrated salts (maicly sodium nitrate waste), and incinerator ash. Details of this work are described elsewhere $[2,3,4,5]$.

The approach taken in this study was to perform a series of "survey" type experiments using various polymerization systems to find the most economical and practical method for further iri-depth studies.

Compactible dry bulk waste was stabilized with two different monomer systems: styrene-trimethylolpropane trinethacrylate (TMPTMA) and polyester-styrene, in laboratory-scale experiments. Stabilization was accomplished by wetting or soaking compactible waste (before or after compaction) with monomers, which were subsequently polymerized. Three stabilization methods are described. One involves the in-situ treatment of compacted waste with monomers in which a vacuum technique is used to introduce the binder into the waste. The second method involves the alternate placement and compaction of waste and binder into a disposal container. In the third method, the waste is treated before compaction by wetting the waste with the binder using a spraying technique.

A series of samples stabilized at various binder-to-waste ratios were evaluated through water immersion and compression testing. The compaction pressure used for most of the samples was 50 psi. The binder requirements were reduced considerably due to reduction in voids when the pressure was increased to 1,000 psi. Volume reduction and uniformity in the application of binder can be improved further by shredding of the waste prior to treatment. Samples with binder-to-waste ratio of 0.3 or more retained their geometric configuration after immersion in water for $\sim 190$ days with little or no change in compressive strength. A compressive strength of $\sim 600$ psi was measured for samples with a binder-to-waste ratio of 0.3 while samples with higher ratios had compressive strengths of 3,000 psi or greater.

Full-scale studies were conducted by stabilizing two 55-gallon drums of real compacted waste. The binder, polyester-styrene, was introduced into the drum using the vacuum technique. After curing, the drums were cut into segments for product evaluation. A good correlation was observed between laboratcry-scale 
specimens of simulated compacted waste and the full-scale samples in terms of binder requirements, processability and the temperatures of the exothermic reaction. The measured peak temperature was $120^{\circ} \mathrm{C}$.

The results of this preliminary study indicate that the integrity of compacted waste forms can be readily improved to ensure their long-term durability in disposal environments. 
1. COMPACTIBLE Waste $\ldots \ldots \ldots \ldots \ldots \ldots \ldots \ldots \ldots \ldots \ldots \ldots \ldots \ldots \ldots \ldots \ldots$

1.1 Classification and Composition $\ldots \ldots \ldots \ldots \ldots \ldots \ldots \ldots \ldots \ldots \ldots$

1.2 Current and Anticipated Treatment Methods $\ldots \ldots \ldots \ldots \ldots \ldots \ldots \ldots \ldots$

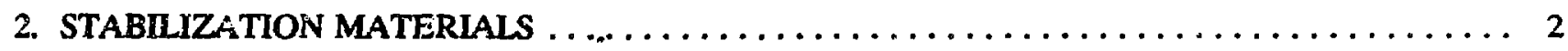

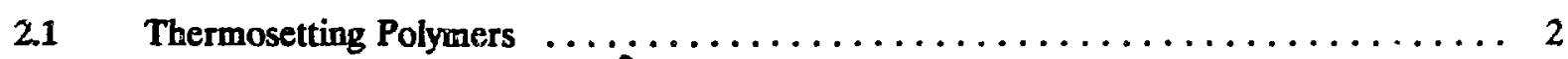

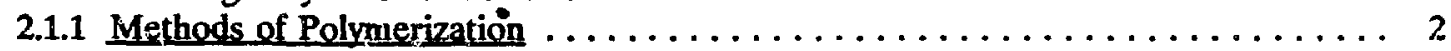

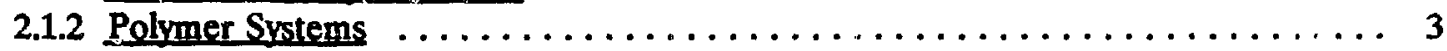

2.1.2.1 Styrene-Trimethylolpropane Trimethacrylare (TMPTMA). ..... 3

2.1.2.2 Polyester-Styrene $\ldots \ldots \ldots \ldots \ldots \ldots \ldots \ldots \ldots \ldots \ldots \ldots \ldots$

3. INVESTIGATION OF STABILIZATION METHODS $\ldots \ldots \ldots \ldots \ldots \ldots \ldots \ldots \ldots \ldots$

3.1 Post-Treatment of Compacted Waste $\ldots \ldots \ldots \ldots \ldots \ldots \ldots \ldots \ldots \ldots \ldots$

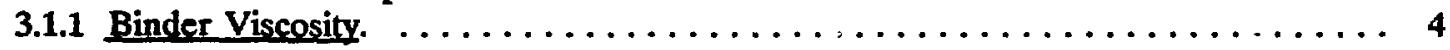

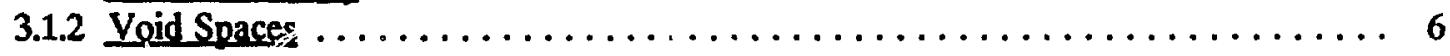

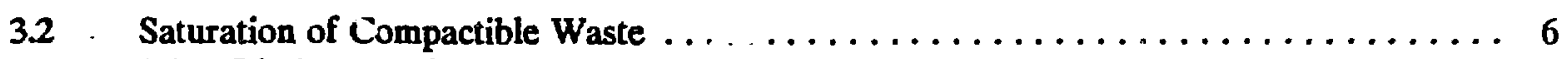

3.2.1 Binder Requirements. . . . . . . . . . . . . . . . . . . 9

3.3 Pre-Treatment of Compactible Waste $\ldots \ldots \ldots \ldots \ldots \ldots \ldots \ldots \ldots \ldots$

4. EVALUATION OF WASTE FORMS $\ldots \ldots \ldots \ldots \ldots \ldots \ldots \ldots \ldots \ldots \ldots \ldots \ldots \ldots$

4.1 Compressive Strength Measurements $\ldots \ldots \ldots \ldots \ldots \ldots \ldots \ldots \ldots \ldots \ldots$

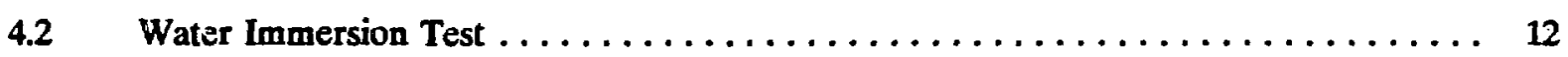

4.2.1 Samples Stabilized with a Mixture of Styrene-TMPTMA. . . . . . . . . 12

4.2.2 Samples Stabilized with Polvester-Styrene. . . . . . . . . . . . . . . 14

$4.3 \quad$ Bindegradation Test $\ldots \ldots \ldots \ldots \ldots \ldots \ldots \ldots \ldots \ldots \ldots \ldots \ldots \ldots \ldots \ldots$

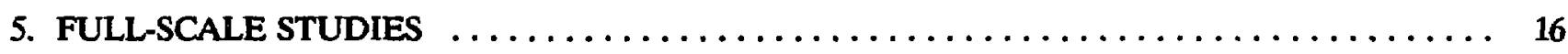

5.1 Stabilization of $55-$ Gallon Drums of Compacted Waste $\ldots \ldots \ldots \ldots \ldots \ldots$

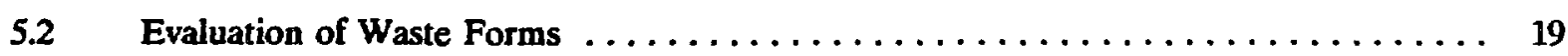

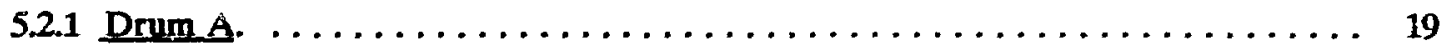

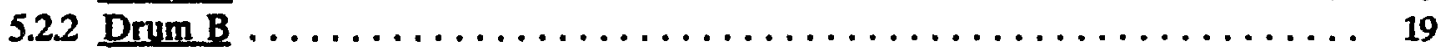

REFERENCES $\ldots \ldots \ldots \ldots \ldots \ldots \ldots \ldots \ldots \ldots \ldots \ldots \ldots \ldots \ldots \ldots \ldots \ldots \ldots \ldots \ldots \ldots$ 


\section{List of Figures}

Figure 3.1 Schematic of post-îreatment of compacted waste using a vacuum technique. . . . . . 5

Figure 3.2 Effect of binder viscosities on binder-to-waste ratios for laboratory-size samples of

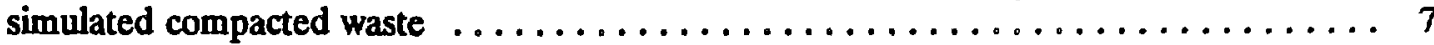

Figure 3.3 Schematic of the saturation method for stabilization of compactible waste $\ldots \ldots \ldots \ldots$

Figure $3.4 \quad$ Schematic of pre-compaction treatment of compactible waste $\ldots \ldots \ldots \ldots \ldots$

Figure 4.1 Effects of water immersion on treated and untreated compacted waste samples.

Sample A: $\quad$ Stabilized compacted waste after immersion in water for 195 days.

Sample B: Unstabilized compacted waste (not subjected to immersion in water).

Sample C: $\quad$ Unstabilized compacted waste after immersion for 3 hours. . . . . . 16

Figure 5.1 Increases in temperature of a full-scale waste form as a function of time during polymerization of the binder.

Figure 5.2 Apparatus used to demonstrate the stabilization of a 55-gallon drum of compacted waste by the vacuum technique. $\ldots \ldots \ldots \ldots \ldots \ldots \ldots \ldots \ldots \ldots \ldots \ldots$

Figure 5.3 - A clam-shell type drum heater used to initiate the polymerization of a treated 55gallon drum of compacted waste. . . . . . . . . . . . . . . . . . . 19

Figure $5.4 \quad$ Cross-sections of a stabilized 55 -gallon drum waste form. $\ldots \ldots \ldots \ldots \ldots \ldots$

Figure $5.5 \quad$ A slose-up view of a stabilized full-scale waste form. $\ldots \ldots \ldots \ldots \ldots \ldots$ 


\section{List of Tables}

\section{Table 4.1}

Table 5.1 Compressive Strengths of Samples from Stabilized Full-scale Compacted Waste Form 


\section{COMPACTIBLE WASTE}

\subsection{Classification and Composition}

One of the major categories of LLW is dry bulk waste. It constitutes a high volume waste produced at all of the DOE sites on a continuous basis. Dry bulk waste consists of laboratory trash such as contaminated paper, glassware, plastics, protective clothing, wood, rubber, tools, piping, equipment fabricated from ceramiss or metal, construction rubble and contaminated soil. A convenient way of grouping these wastes is according to possible treatment process characteristics, i.e., compactible/non-compactible and combustible/non-combustible. Often these categories overlap since combustible wastes usually are also compactible. About $20-40 \%$ of bulk waste is compactible.

The levels of radioactivity are very low in most of the compactible waste. Its radiological character varies from site to site depending on the specific functions of the facilities. For example: at Oak Ridge the main contaminants in the waste generated at the $X-10$ Facility are fission products, while the waste from the K-25 Facility contains $U$ and $T c$, and the waste from the Y-12 Facility contains $U$ and $T h$. At the Savannah River Plant, the compactible waste contains mostly fission products. However, the waste generated at the Rocky Flats Plant is contaminated mostly with $\mathrm{U}, \mathrm{Pu}$ and Am.

\subsection{Current and Anticipated Treatment Methods}

The most common practice for treating compactible waste has been to bale the waste with metal ties or place the waste with or without compaction into 55-gallon drums, or boxes made of cardboard, wood, or metal. The usual compaction pressure is 50 psi, achieving volume reduction factors of two to six, depending on the composition of the waste and the equipment used.

For many of the sites, future plans for the treatment of compactible waste include incineration, s'iredding, or supercompaction. At supercompaction pressures of 4,000 to 10,000 psi, factors of $6-10$ in volume reduction are achieved for a 55-gallon drum. These drums are reduced in height to 48 inches. 


\section{STABILIZATION MATERIALS}

The function of the stabilization materials is to coat or impregnate the waste to prevent permeation of water and attack by micronrganisms. Polymers were chosen for this study because of their low waterpermeability, long-term durability, resistance to biodegradation and previous BNL experience in impregnation of various types of materials with polymers $[6,7]$.

\subsection{Thermosetting Polymers}

Successful stabilization was accomplished by using styrene monomer in combination with other monomers and a catalyst system to form a cross-linked thermoset polymer. Once a thermoset is formed through application of certain chemicals or heat, it can not be renelted or reformed.

Styrene was selected as a co-monomer because of its low, near-water viscosity, low cost and availability. A low viscosity material is important for complete penetration of the compacted waste. However, when partial impregnation or coatings are desired, materials of higher viscosities can be used. A wide range of viscosities can be obtained by combining styrene in various proportions with monomers of higher viscosities.

2.1.1 Methods of Polymerization. A polymerization reaction is activated by the addition of a peroxide type catalyst which decomposes to form very reactive free radicals that become the centers of polymer growth. The decomposition of the catalyst can be activated by heating the system to the temperature at which the catalyst decomposes or by addition of promoters which will induce the decomposition at ambient temperature. The cure time depends on parameters such as temperature, catalyst or catalystpromoter combinations and concentrations, and admixtures which can be used to retard or accelerate the rate of polymerization. The polymerization reaction is exothermic, resulting in increased temperatures, which in turn accelerate free-radical formation. This is called autoacceleration and may result in an excessive temperature rise due to an increased polymerization rate.

Styrene monomer is not amenable to room temperature polymerization by a catalyst-promoter system, therefore, external heating is required to initiate the polymerization reaction for an effective cure within a reasonable period of time. However, in combination wish other types of monomers, such as trimethylolpropane-trimethacrylate (TMPTMA) or polyester resin, styrene can be cured at room temperature through the use of catalyst-promoter systems. 


\subsubsection{Polymer Systems}

2.1.2.1 Styrene - Trimethylolpropane Trimethacrylate (TMPTMA). A styrene-TMPTMA mixture was fieferred for the initial studies since it has a lower viscosity (1-2 cps) and better wetting properties than the polyester-styrene mixture. The monomer mixture was used in conjunction with a catalyst-promoter system which induced polymerization at room temperature, in 15-20 minutes. The catalyst used is benzoy! peroxide and the promoter is $\mathbf{N}$, $\mathbf{N}$-dimethylaniline (DMA).

In these studies, mixtures of siyrene-TMPTMA containing 10-40 wt\% TMPTMA were used. Increasing the amount of TMPTMA from 10 to $40 \mathrm{wt} \%$ decreases the amount of catalyst required and the curing time.

2.1.2.2 Polyester-Styrene. Mixtures of unsaturated linear polyester resins dissolved in styrene are commercially available in varying proportions, depending on their intended use. Most mixtures contain 50-70 wt\% polyester, with a viscosity typically of $250 \mathrm{cps}$. By increasing the amount of styrene in the mixture to about $90 \mathrm{wt} \%$, the viscosity is reduced to approximately $2.5 \mathrm{cps}$. The polymerization reaction can be initiated thermally or chemically. In these studies azo-bis-isobutyronitrile (AIBN) was used as the catalyst. The reaction was initiated thermally by heating to $50^{\circ} \mathrm{C}$. 


\section{INVESTIGATION OF STABILIZATION METHODS}

Three methods for the stabilization of compactible waste were investigated. These methods differ from each other according to whether the binder comes in contact with the waste before, during or after compaction. These studies focus primarily on a compaction pressure of $\approx 50$ psi since it represents operating pressures of most compactors in use at the present. However, in a few experiments the waste was compacted to $\approx 1,000$ psi to simulate a pressure more closely associated with supercompactors being tested at several DOE sites.

The simulated waste used in these experiments consisted mostly of paper $(\approx 70 \%)$ and a mixture of rubber gloves, polyethylene bags, and rags. In experiments determining the effect of binder viscosities and void spaces a more homogeneous waste was required, therefore, only paper was used.

\subsection{Post-Treatment of Compacted Waste}

A vacuum technique was used to introduce a binder into the waste which had been compacted into a container. The binder, which enters the container through an opening near the base, is gravity-fed through the tightly packed matrix of the waste. Evacuating the container from the top removes air from the system to ensure a uniform distribution of binder. A schematic of the system is shown in Figure 3.1. The binder is introduced into the container until it completely covers the waste. This can be controlled by mechanical or automatic devices which shut off the binder feed at a predetermined level. As an optional step, any excess binder is allowed to drain through the opening at the bottom.

3.1.1 Binder Viscosity. The viscosity of the bincer is an important parameter determining the effectiveness of the process and the properties of the final stabilized waste package.

To determine the effects of the viscosity of a binder on the post-treatment of compacted waste using a vacuum technique, laboratory-scale waste forms were stabilized using a polyester-styrene (PES) binder with viscosities ranging from 2.5 to 260 cps. The PES contained $1 \%$ AIBN catalyst. Samples $(d=7 \mathrm{~cm}, \mathrm{~h}=5-6$ $\mathrm{cm}$ ) consisting of $100 \mathrm{~g}$ of simulated (non-radioactive) waste were compacted into metal containers at $50 \mathrm{psi}$ compaction pressure. A hole was drilled near the bottom of the container and the container was placed into a reservoir of PES. The container was covered with a specral cap which had a viewing port and a vacuum port built into it. The container was the evacuated until the binder reached the top of the waste, as observed through the viewing port. The cap was replaced with a conventional cap and the hole at the 


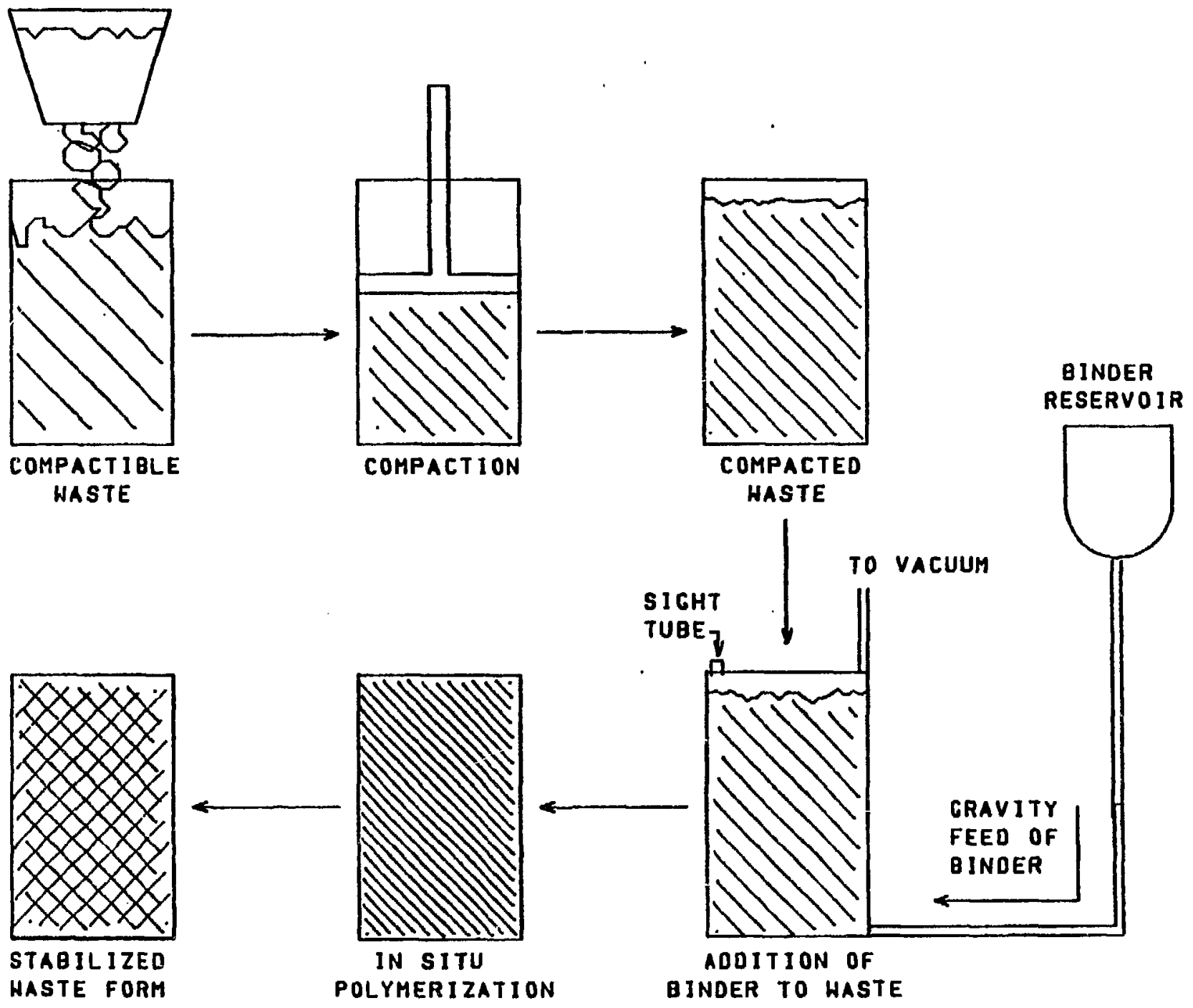

Figure 3.1 Schematic of post-treatment of compacted waste using a vacuum technique. 
bottom of the container was plugged to prevent the loss of the binder. The container was heated to $50^{\circ} \mathrm{C}$ to decompose the catalyst and initiate the polymerization reaction. The rate at which polymerization occurs depends on the decomposition rate of the catalysi. At $50^{\circ} \mathrm{C}$ the decomposition is rapid and polymerization is complete in $\approx 3 !$ minutes. After curing, the container was cut away from the waste form and the waste form was weighed to determine the amount of binder used. Because the laboratory-scale waste forms have short pathways for the binder to follow, the total time allowed for introduction of the binder was arbitrarily set at $<5$ minutes. With this time limit, only binders with viscosities of $\approx 60$ cps or less could be successfully introduced throughout the waste matrix, using the vacuum technique. The time required to fill the container decreased from $\approx 5$ minutes to $\approx 30$ seconds when the viscosity of the binder was reduced from 56 cps to 2.5 cps. However, at viscosities of $\mathbf{3 0} \mathrm{cps}$ or lower, the required amount of binder remained constant. This is probably due to the rate of saturation of the waste matrix at a binder viscosity of $<30 \mathrm{cps}$. At a viscosity of $56 \mathrm{cps}$, the binder to waste ratio (by weight) was $\approx 1.2-1.3$, as compared to an average value of 1.4 for the lower viscosity binders. To check for uniformity and completeness of treatment, the samples vere crosssectioned and visually examined. It was observed that the binder had permeated throughout the waste, including the voids, to produce a hard monolith.

3.1.2 Void Spaces. The void volume in a container of waste compacted at pressures of 50 psi was considerable, as observed from cross-sectioned samples. Because of the presence of voids, more binder is used than necessary. To minimize binder requirements, experiments were performed with a series of samples identical to those used to determine the effects of binder viscosity. After addition of binder, the containers were allowed to drain off excess binder for 10 minutes prior to polymerization of the polyesterstyrene. The results are presented graphically in Figure 3.2. With lower viscosity binders, the binder to waste ratio was reduced to 1.0. The drop in the ratio observed for the 56 cps viscosity binder demonstrates the lower absorption of higher viscosity binders. The samples were also cross-sectioned and visually examined. Complete coating of the waste by the binder was observed although the void areas were mostly depleted of binder. While the absence of binder from the voids reduced the amount of binder required, it also reduced the overall compressive strength of the waste form. Even so, the compressive strength of the drained samples with binder-to-waste ratio of 1.0 was approximately 2,000 psi, while the undrained samples had a compressive strength of 3,500 psi.

\subsection{Saturation of Compactible Waste}

In this method, alternate layers of waste and binder are placed in the container and subsequently compacted. This is repeated until the container is filled. A schematic of the process is given in Figure 3.3. 


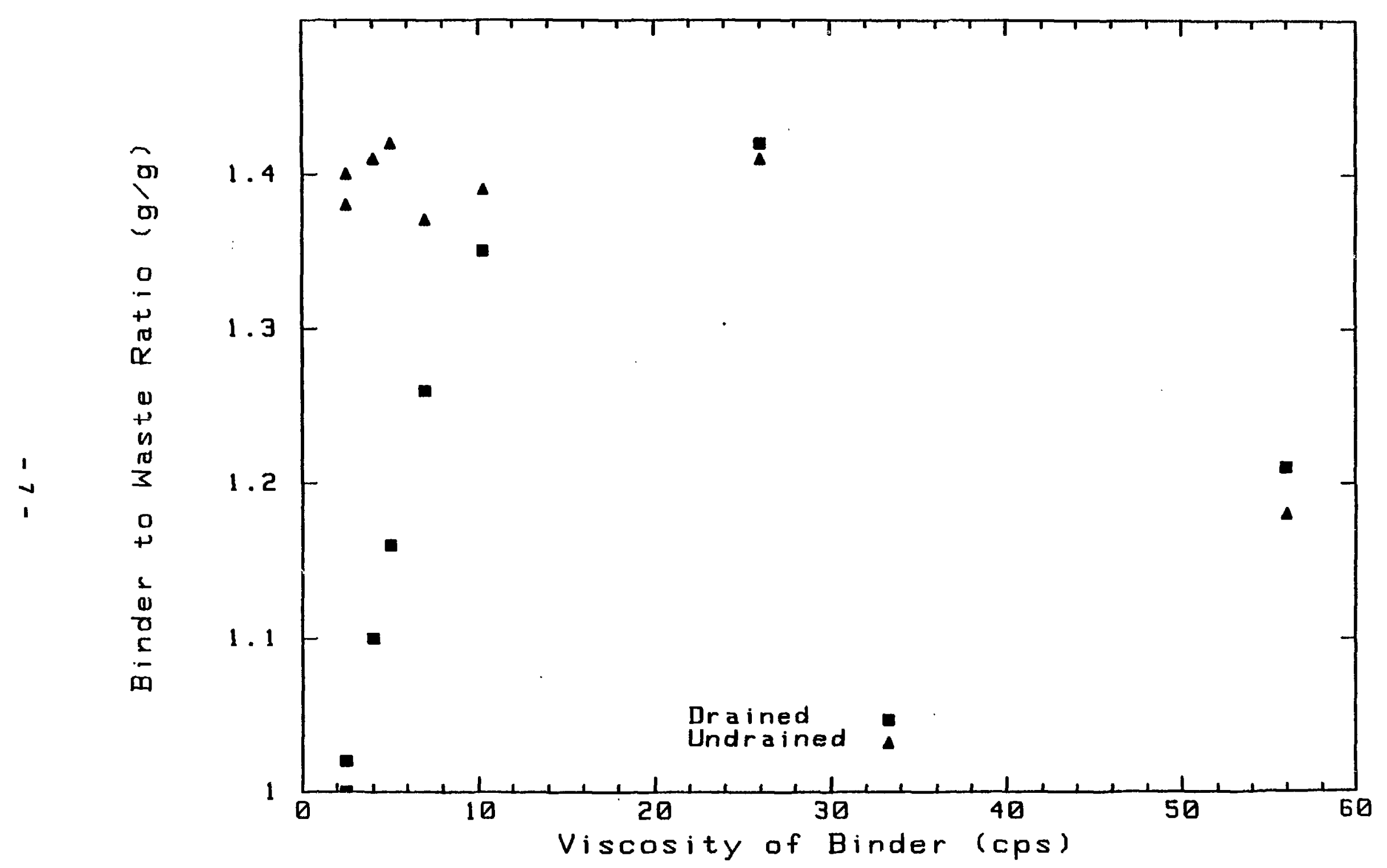

Figure 3.2 Effect of binder viscosities on binder-to-waste ratios for laboratery-alze samples of slmulated compacted waste. 

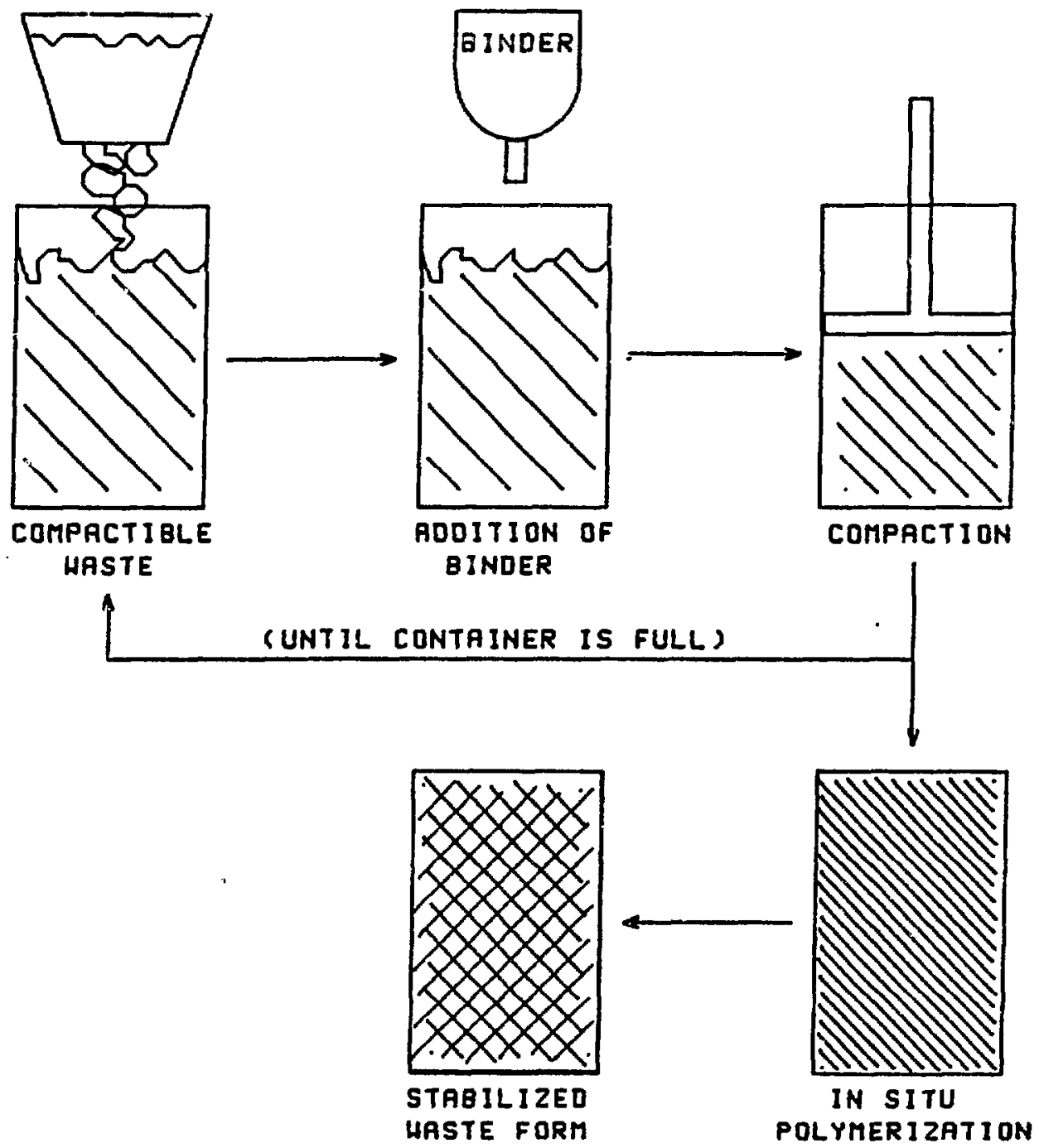

Figure 3.3 Schematic of the saturation mothod for stablilzation of compretible waste. 
A sufficient amount of binder is required to allow dispersion and saturation of the binder throughout the waste matrix during intermittent compaction of the waste. As in the case of the post-treatment method, an important process parameter is the viscosity of the binder. In this case, a binder with a low viscosity is desirable for efficient wetting of the waste. A highly viscous binder does not disperse rapidly and may not completely saturate the waste. Additionally, it may cause a localized pressure build-up which could distort or rupture the container during compaction, as experienced in the laboratory.

Laboratory studies using this system focused on styrene-TMPTMA as the binding agent. This mixture maintains a low viscosity over a broad range of styrene-TMPTMA compositions. Even at 40wt\% TMPTMA, the viscosity is close to that of water $(\approx 2 \mathrm{cps})$, and the binder has excellent wetting capabilities allowing the binder to rapidly disperse throughout the waste.

3.2.1 Binder Requirements. The following experiments were performed to determine the monomer requirements for the saturation method. The amount of binder (styrene-40 wt\% TMPTMA) used per sample was varied to yield binder-to-waste ratios of $0.5,0.75,1.0$ and 1.2 at 50 psi compaction pressures and $0.4,0.5$ and 0.75 at 1,000 psi compaction pressures. One hundred grams of simulated compactible waste was divided into four portions. An amount of binder was also divided into four parts. One part of the waste and one part of the binder were placed into metal containers and compacted to 50 psi. This procedure was repeated three times with the remaining portions of the waste and binder. In a similar sequence, a 1,000 psi compaction pressure was used. After final compaction, the waste form was allowed to cure. A promotercatalyst combination was chosen to allow room temperature initiation of the polymerization reaction. The promoter, DMA, was used in combination with a peroxide catalyst. After polymerization was completed, the waste forms were removed from the containers and examined for completeness and uniformity of treatment. It was observed that in samples with a binder-to-waste ratio of at least 1.0, at a compaction pressure of 50 psi, the binder was well dispersed throughout the waste and the waste forms were hard monoliths. The same held true for samples compacted at 1,000 psi with a binder-to-waste ratio of 0.5 or greater. The increased compaction pressures $(1,000 \mathrm{psi})$ greatly reduced the binder requirements. To determine the amount of TMPTMA necessary for complete polymerization, a set of samples was prepared at a binder-to-waste ratio of 1.0 using mixtures of styrene-TMPTMA which contained 10, 20, 30 and 40 wt\% TMPTMA. All samples were successfully polymerized and became hard monoliths, although the amount of catalyst required and the curing times decreased with increased TMPTMA cuncentration. 


\subsection{Pre-Treatment of Compactible Waste.}

The first and second treatment methods, described in 3.1 and 3.2, involve "in-container" treatment of the waste. In a third method, the waste is treated prior to placement into the container for compaction. The waste is pre-treated by uniformly applying the binder with a spray gun, or by mixing the waste and binder in a tumbler. The spraying technique was selected for this study because the binder contact time is short and a uniform coating could be applied to shredded or "as is" waste, using a minimum amount of binder. Preshredding of the waste will improve volume reduction and uniformity in the application of the binder. In addition, the technology for spraying binders, such as polyester-styrene, is well developed and has been commercially used for several decades by the paint and fiberglass industries. A schematic of the spraying technique is shown in Figure 3.4.

Laboratory-scale waste forms were prepared by spraying shredded simulated compactible waste with a polyester-styrene binder having a viscosity of $260 \mathrm{cps}$. In contrast to the previously described methods which required the use of low viscosity tinders, a high viscosity binder could be used in this method to achieve minimal absorption of the binder with sufficient wetting of the waste to attain good adhesion after compaction. A catalyst, (AIBN), was added to the polyester-styrene binder so that polymerization could be initiated by heat after compaction. A promoter-catalyst system can be employed as an alternative, so that polymerization occurs at room temperature. To avoid premature polymerization of the binder using a promoter-catalyst system, a dual spray system can be used whereby the binder is applied in two separate streams, one of which contains the promoter and the other the catalyst. Both streams combine on contact with the waste prior to the compaction step.

Samples with binder-to-waste ratios of $0.2,0.3$ and 0.4 were prepared by spraying varying amounts of binder onto 100 -gram increments of shredded waste. The wetted wastes were compacted at 50 psi and polymerized. Attempts at using lower proportions of binder resulted in waste forms which delaminated upon removal from the compaction container. When 1,000 psi compaction pressures were used, waste forms with a binder-to-waste ratio of 0.1 were produced. All of the samples were subjected to compression strength and immersion tests. 


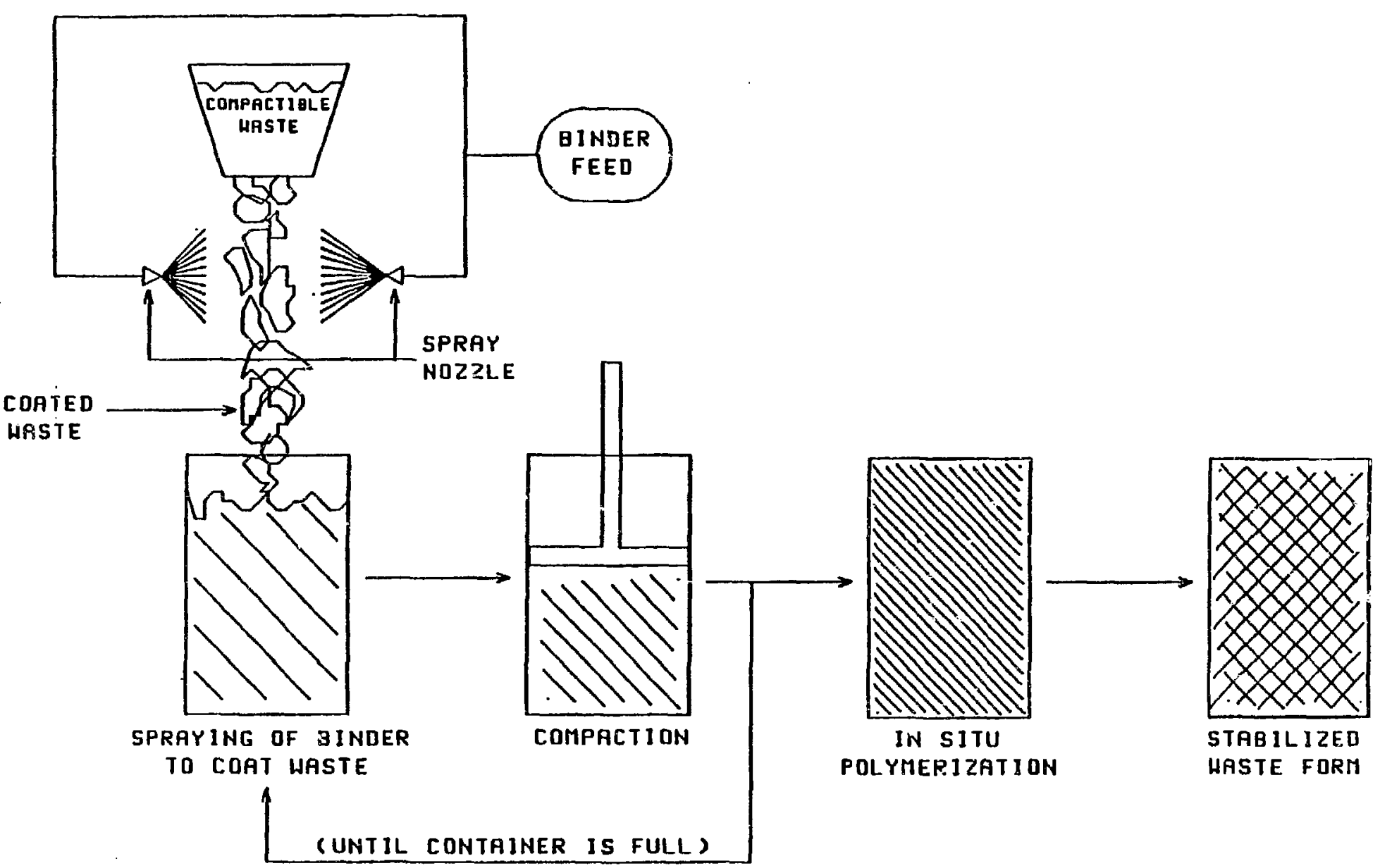

Figure 3.4 Schematic of pre-compaction treatment of compactible waste. 


\section{EVALUATION OF WASTE FORMS}

The integrity of the stabilized waste forms was examined through a series of tests suggested by the Nuclear Regulatory Commission in its Branch Technical Position Paper on Waste Form [8] in support of 10 CFR 61 [9]. The tests were selected because they relate to problems associated with compacted waste in disposal, such as swelling in the presence of water and biodegradation.

\subsection{Compressive Strength Measurements}

Some of the preliminary testing in this program was performed in accordance with ASTM C-39, "Compressive Strength of Cylindrical Concrete Specimens." This test was considered appropriate for samples with high binder-to-waste ratios where distinct break points were observed. However, as the binder-to-waste ratio was reduced, the samples showed a compressive yield point with no distinct break point. Therefore, ASTM D-695, "Compressive Properties of Rigid Plastics," was chosen for testing such waste forms.

The compressive strengths for cylindrical test specimens, $7.1 \mathrm{~cm}$ in diameter and $11.4 \mathrm{~cm}$ in length, are given in Table 4.1. Those which were fabricated using the vacuum technique had binder-to-waste ratio of 1.0. For preparation of samples with lower ratios, the spraying technique had to be used since it requires less binder. These include the samples made with two binder types and various binder-to-waste ratios. The compressive strengths stay essentially the same until the binder-to-waste ratio is reduced to 0.3 , at which point a sudden drop in the compressive yield point is observed. Finally, at a ratio of 0.2 , the yield point is no longer discernible. The strength of the waste form with high binder-to-waste ratio is mainly due to the amount of polymer present. At the lower binder-to-waste levels, the binder is a small percent of the total waste form and any added strength of the waste form due to the binder is masked by the compactible nature of the waste.

\subsection{Water Immersion Test}

4.2.1 Samples Stabilized with a Mixture of Styrene-TMPTMA. Preliminary studies on the effect of water on stabilized compacted waste were performed for samples containing $75 \mathrm{~g}$ simulated waste and $70 \mathrm{~g}$ of 60-40 styrene-TMPTMA binder. The cylindrical samples, $7.1 \mathrm{~cm}$ in diameter and $4.1 \mathrm{~cm}$ in length, were placed in deionized water at room temperature for 90 days. Only slight dimensional changes were detected (3\% in diameter and $8 \%$ in length) at the end of that period. The samples were re-immersed for a total of 195 days, after which time no further dimensional changes were noted. In Figure 4.1, relative volumes are 
Table 4.1

COMPRESSIVE STRENGTH OF STABILIZED COMPACTED WASTE

\begin{tabular}{|c|c|c|c|c|c|c|c|}
\hline $\begin{array}{l}\text { Binder } \\
\text { Type }\end{array}$ & $\begin{array}{l}\text { Styrene } \\
\text { (vi\%) }\end{array}$ & $\begin{array}{l}\text { Binder-to-Waste } \\
\text { Patlo }\end{array}$ & $\begin{array}{l}\text { Blnder Applice- } \\
\text { tlon Tochnique }\end{array}$ & $\begin{array}{l}\text { Compaction } \\
\text { Pressure } \\
\text { (psil) }\end{array}$ & Control & $\begin{array}{l}\text { After } 90 \text { daye } \\
\text { immaralon }\end{array}$ & $\begin{array}{l}\text { After Ble- } \\
\text { degradation } \\
\text { (Becterla) }\end{array}$ \\
\hline $\begin{array}{l}\text { Styrene- } \\
\text { TMPTMA }\end{array}$ & 60 & 1.0 & vacuum & 50 & $3070 \geq 140(3)^{\mathrm{b}}$ & $2930+280(3)$ & $2960 \times 210$ \\
\hline $\begin{array}{l}\text { Polyester- } \\
\text { Styrene }\end{array}$ & $65 \cdot 70$ & 1.0 & vacuum & 50 & $3500,1330(3)$ & $3580 \pm 120(2)$ & N.A. ${ }^{c}$ \\
\hline $\begin{array}{l}\text { Polyester- } \\
\text { Styrene }\end{array}$ & 50 & 0.4 & sprayling & 50 & $4200 \times 730$ & $3800+350$ (2) & N.A. \\
\hline $\begin{array}{l}\text { Polyester- } \\
\text { Styrene }\end{array}$ & 50 & 0.3 & spraying & 50 & $690 \pm 60 \quad$ (2) & $550 \pm 40(2)$ & N.A. \\
\hline $\begin{array}{l}\text { Polyester- } \\
\text { Styrene }\end{array}$ & 50 & 0.2 & spraying & 50 & $\begin{array}{l}\text { Alo distinct } \\
\text { ylold point (2) }\end{array}$ & $\begin{array}{l}\text { No distinct } \\
\text { ylold point (2) }\end{array}$ & N.A. \\
\hline $\begin{array}{l}\text { Polyester- } \\
\text { Styrene }\end{array}$ & 50 & 0.1 & spraying & 1000 & $\begin{array}{l}\text { No distinct } \\
\text { ylotd point (2) }\end{array}$ & Falled fost (2) & N.A. \\
\hline
\end{tabular}

a) $1 \mathrm{pal}=6.98 \times 10^{3} \mathrm{~Pa}$ (Pascal)

b) Number of samples tested

c) Not avallable 
compared for: stabilized compacted waste after immersion in water for 195 days (A), compacted waste "as is" (B), and compacted waste after a 3-hour exposure to water (C). A twofold increase in volume can be seen between samples $B$ and $C$.

Specimens of sirnulated compacted waste $(7.1 \mathrm{~cm}$ in diameter, $11.4 \mathrm{~cm}$ in length) stabilized with styrene-TMPTMA at a binder-to-waste ratio of 1.0, using the vacuum technique, were immersed in vater for 90 days. After the immersion period, the dimensional shanges and compressive strengths were measured. The dimensional changes were small, averaging less than $3 \%$ in the axial direction and showing no real changes $(+1$ to $-1 \%)$ in the radial direction. The compressive strengths, wiich were not affected by the immersion, are listed in Table 4.1, together with the control vaiues.

4.2.2 Samples Stabilized with Polyester-Styrene. Samples stabilized with polyester-styrene also were subjected to water immersion for 90 days. The binder-to-waste ratios ranged from 0.1 to 1.0. All, except one set, were compacted to $50 \mathrm{psi}$. The one set with a binder-to-waste ratio of 0.1 was compacted to 1,000 psi. Samples with a binder-to-waste ratio of 1.0 were prepared using the vacuum technique, while samples with lower amounts of binder were prepared by the spraying technique. The results are given in Table 4.1, together with the control values. Specimens which had a binder-to-waste ratio of 0.1 and were compacted to 1,000 psi failed the test; the samples were swollen and delaminated at the end of the 90-day period. Specimens with binder-to-waste ratio of 1.0 through 0.3 did not show dimensional changes or loss in compressive strength after the water immersion test. The specimens with binder-to-waste ratios of 0.2 behaved similarly to the control samples in that they did not exhibit a distinct yield point. All samples except those with a binder-to-waste ratio of 0.1 were capable of withstanding pressures of at least 500 psi with less than $10 \%$ axial distortion.

\subsection{Biodegradation Test}

Specimens of compacted waste stabilized with styrene-TMPTMA, with a binder-to-waste ratio of 1.0, were tested according to ASTM G-22, "Determining Resistance of Plastics to Bacteria."

Bacterial growth was not observed on any of the specimens tested. The results of the compressive strength measurements taken after the biodegradation test, given in Table 4.1, are similar to the values obtained for control samples. 


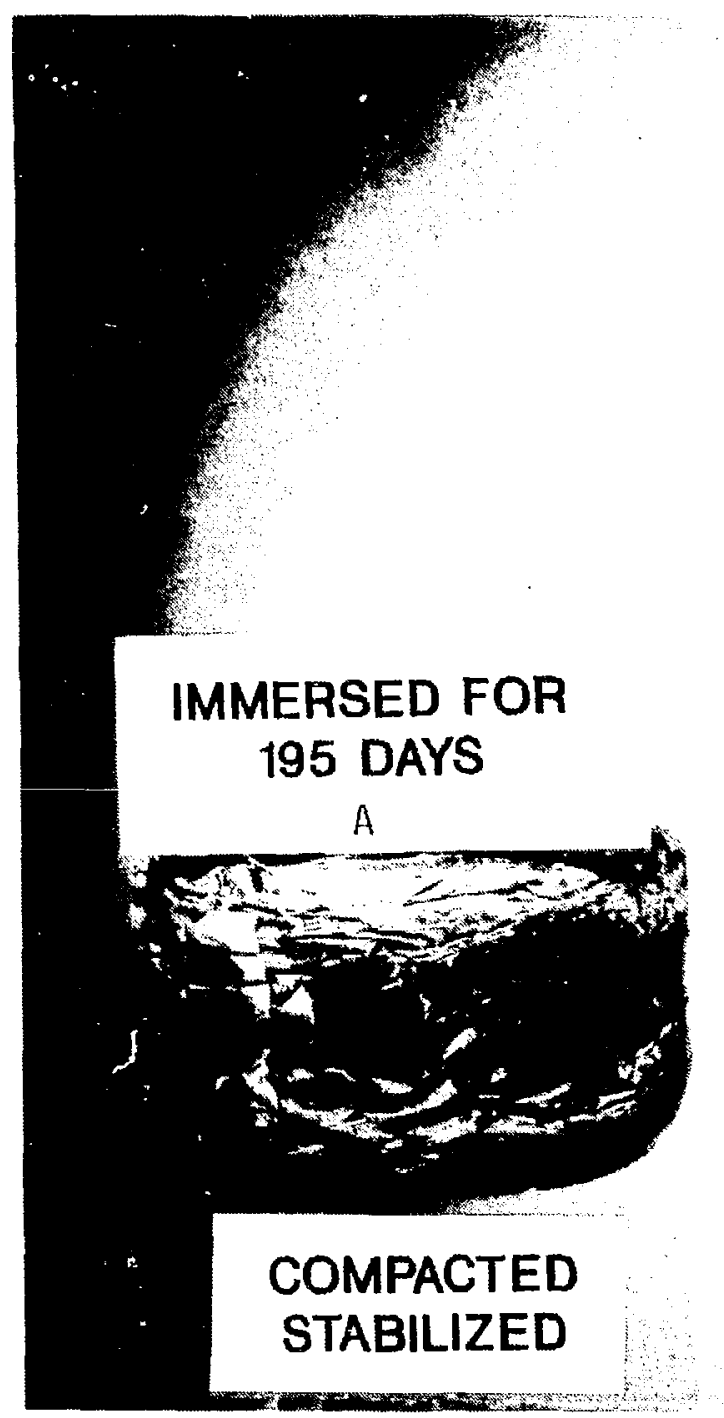

\section{NOT IMMERSED}

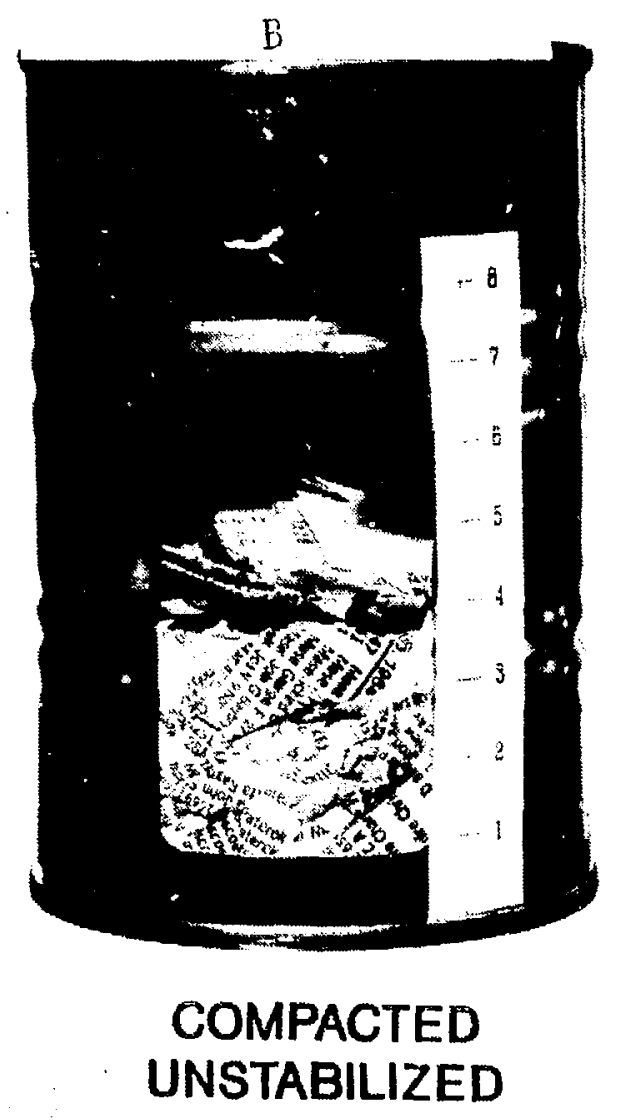

IMMERSED FOR 3 HOURS

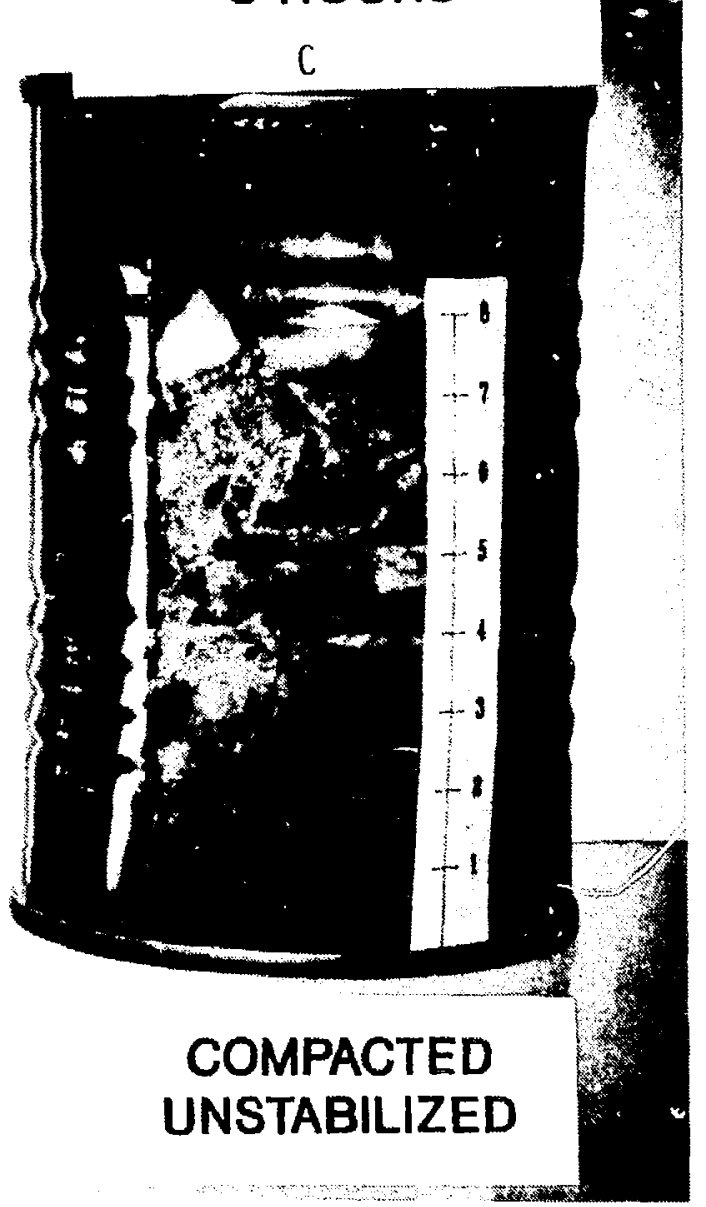

Figure 4.1 Effects of water immersion on treated and untreated compacted waste samples.

Sample A: Stabllized compacted waste after immersion in water for 195 days.

Sample B: Unstabilized compacted waste (not subjected to immersion in water).

Sample C: Unstabilized compacted waste after immersion for 3 hours. 


\section{FULL-SCALE STUDIES}

\subsection{Stabilization of 55-Gallon Drums of Compacted Waste}

To correlate a small-scale laboratory system, using simulated waste, with a full-scale system, two 55gallon drums of real compacted waste were stabilized. In both cases the vacuum technique was used to introduce the binder into the waste drum. The waste is a typical BNL compactible LLW which was compacted at $\approx 50$ psi by the BNL waste-management personnel. The contents of each drum weighed approximately $250 \mathrm{lbs}$. Polyester-styrene (50-50), with a viscosity of $25 \mathrm{cps}$, was used as the binder. Polymerization was catalyzed with AIBN ( $2 \mathrm{wt} \%$ ), and a drum beater at $50^{\circ} \mathrm{C}$ was used to initiate the reaction.

The difference between the two drums was the final amount of binder used. To the first drum (drum $A$ ) $\approx 3$ gallons of additional binder was added from the top to ensure complete saturation of the waste. This resulted in an excess of liquid monomer $(\approx 5 \mathrm{~cm})$ above the waste. During polymerization, the excess binder expanded and bubbled over due to the high exotherm. Excess binder was not added to the second airum (drum B). Instead, binder trapped is voids was allowed to drain from the bottom of the drum for about 2 hours, at which time 5 gallons were recovered. The final amount of binder used for drum $A$ was 29 gallons (232 lbs), with a binder-to-waste ratio of 0.93 . For drum B, 24 gallons (192 lbs) were used, with a final binder-to-waste ratio of 0.77 .

The drums were placed in the drum heater after treatment with the binder and draining of excess binder (in the case of drum B) were completed. To monitor the exotherm during the polymerization reaction, the increases in temperature were monitored with two thermocouples. One thermocouple was placed in the center of the waste form and the other near the outside. Both were located $\approx 41 \mathrm{~cm}$ from the top of the waste form. The temperature readings $\left({ }^{\circ} \mathrm{C}\right)$ for one of the drums are plotted as a function of time in Figure 5.1. Rapid increases were observed after $\approx 330-375$ minutes of heating, marking the peak exothermic temperature at $120^{\circ} \mathrm{C}$.

The experimental equipment for conducting the full-scale treatment of compacted waste using the vacuum technique is shown in Figures 5.2 and 5.3. Figure 5.2 shows binder being gravity-fed into a drum of compacter wr ste while the drum is being evacuated. Protruding from the top of the drum are the thermocouples. The drum heater is situated adjacent to the waste package. Figure 5.3 shows the drum heater in position for initiating the polymerization step. 


\section{Temperature of a Full Scale Waste Form During the Binder Polymerization Step}

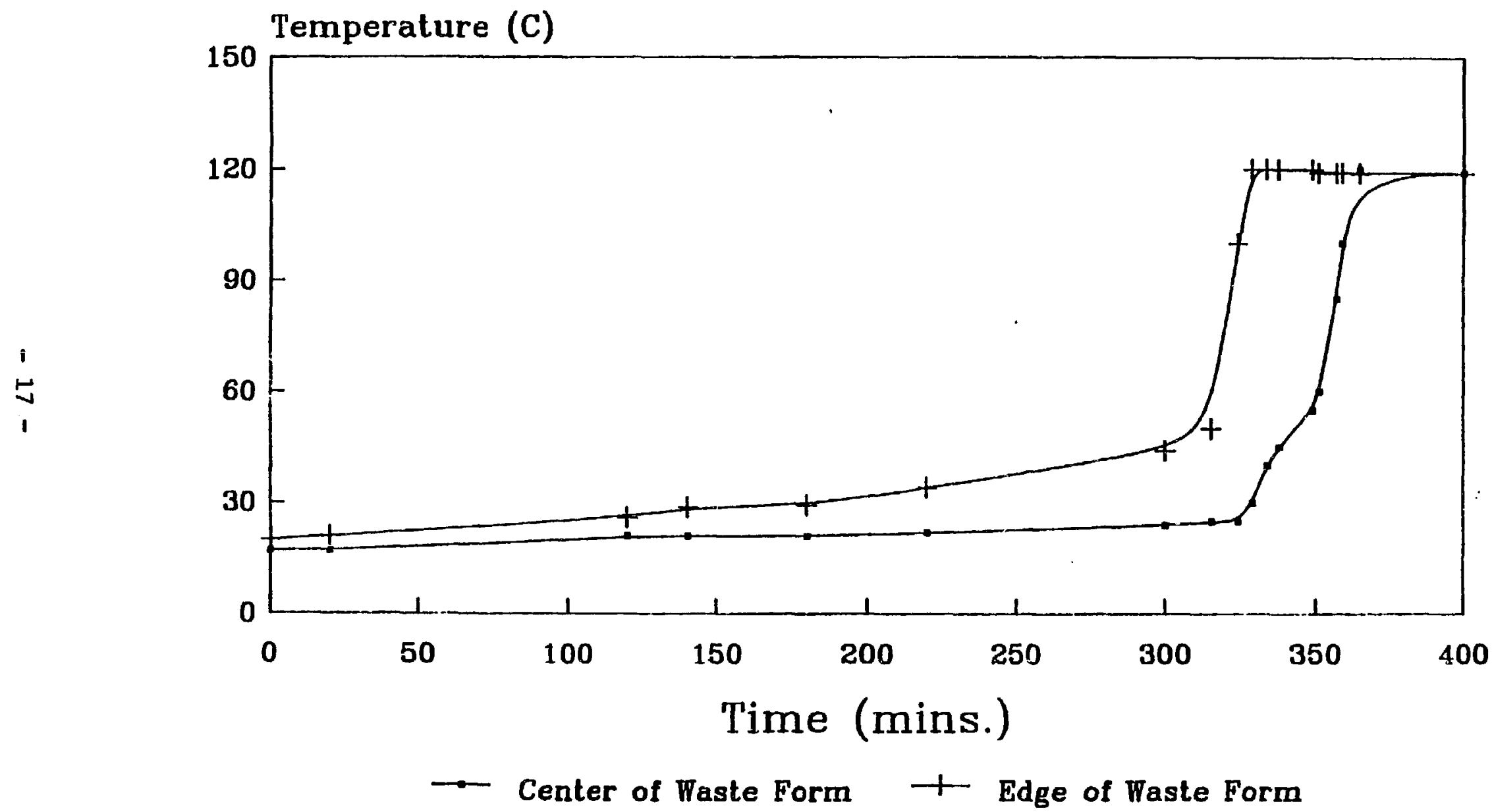

Figure 5.1 Increases in temperature of a full-8cale waste form as a function of time during polymerization of the binder. 


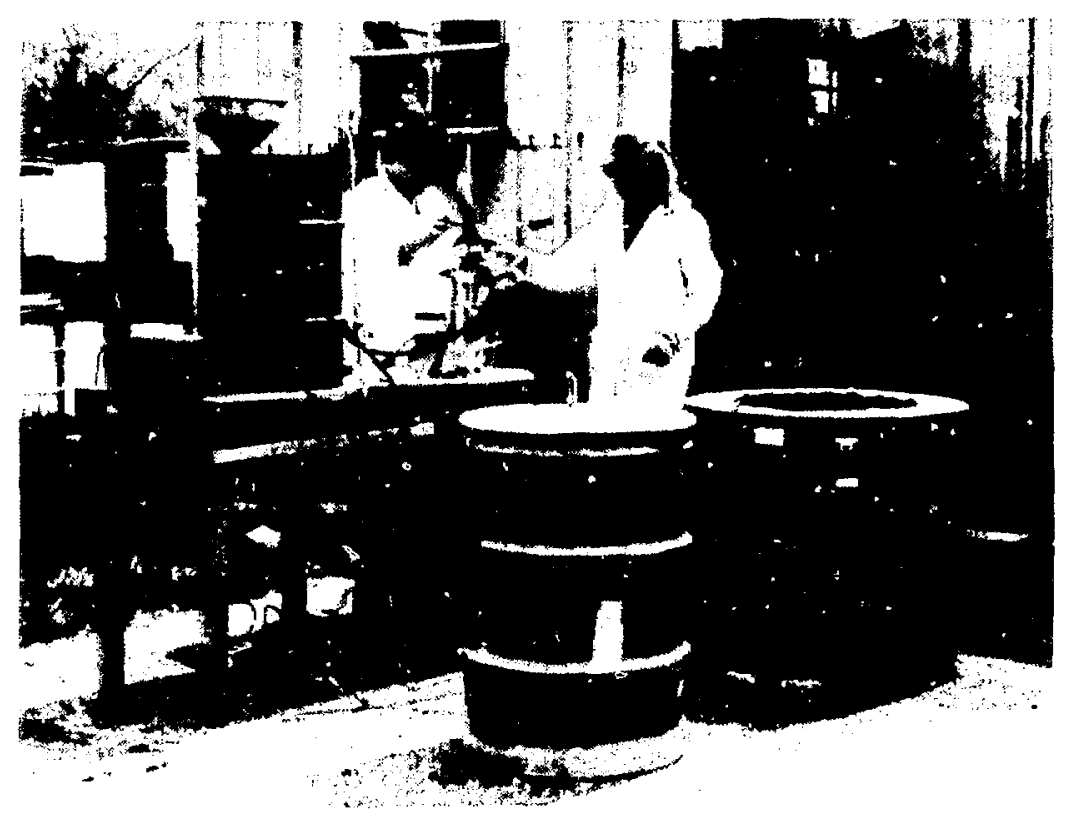

Figure 5.2

Apparatus used to demonstrate the stabilization of a 55-gallon drum of compacted waste by the vacuum technique.

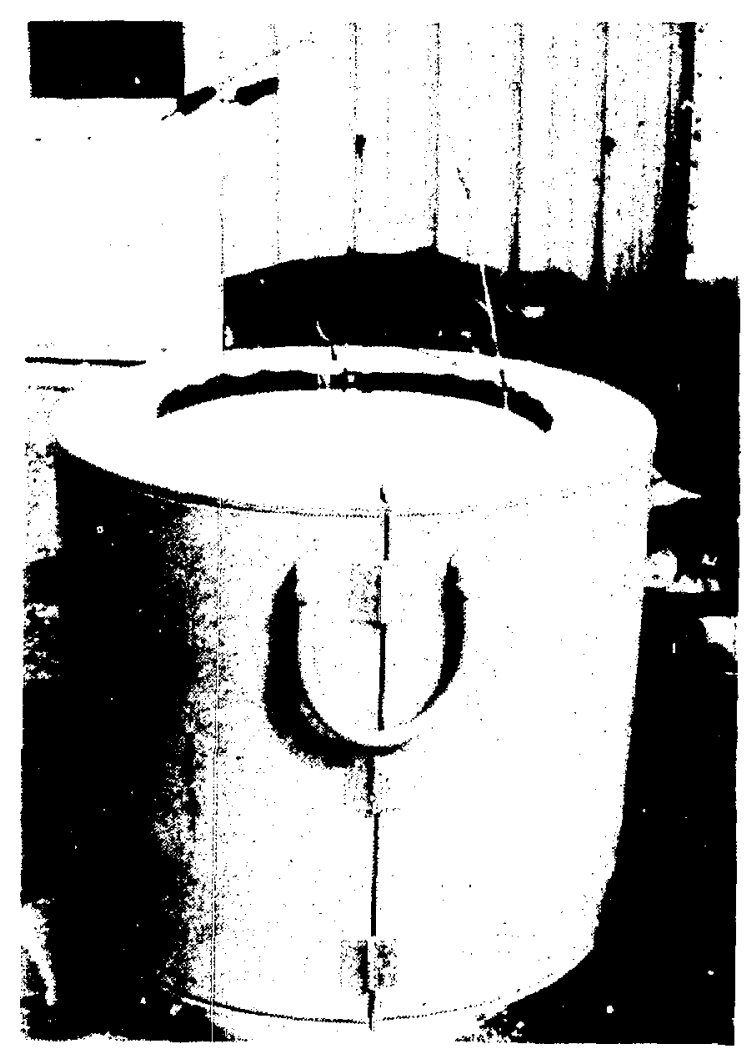

Figure 5.3 A clam-shell type drum heater used to initiate the polymerization of a treated 55gallon drum of compacted waste. 
There was good correlation between the stabilization of the large drums and the small-scale laboratory samples in terms of binder requirements, processability and exotherm temperatures. In both cases, the peak exotherm temperatures were $120^{\circ} \mathrm{C}$.

\section{$5.2 \quad$ Evaluation of Waste Forms}

5.2.1 Drum A. Drum A was cut into sections for inspection. Several of the sections are shown in Figures 5.4 and 5.5. The contents of the entire drum was a solid monolith. Layers of the various types of waste could be distinguished as well as several void spaces, such as an uncrushed box filled with polymerized binder. If the waste is compacted to a greater degree, eliminating major voids, less binder would be required for complete stabilization (shredding prior to compaction would minimize voids).

Three pairs of rectangular samples $(A, B, C)$, each sample approximately $10 \mathrm{~cm} \times 5 \mathrm{~cm} \times 5 \mathrm{~cm}$, were cut from a region $30 \mathrm{~cm}$ to $41 \mathrm{~cm}$ down from the top of the waste form. Three of the samples, one from each pair, were compression tested and three were immersion tested as described in Section 5.2. One pair of samples $(C)$ had been cut across an area containing rubber gloves. The layers of rubber gloves were held together only by a thin layer of the binder. During compression testing, the samples slid apart at the rubber layer, thus contributing to the lower values. The results of the compression strength measurements are presented in Table 5.1. No visual or dimensional changes were observed during immersion in water for 90 days.

The compressive strength of the test pieces of the full-scale waste form was several times lower than that of laboratory-size samples. This was expected, since in the case of the laboratory-size samples, whole samples, which contained small pieces of waste, were tested. In the other case, the testing was performed on samples which represented only a small part of a heterogeneous full-scale waste form. These samples were cut through pieces of waste larger than the samples themselves.

5.2.2 Drum B. The waste form was cored from the top to a depth of about $36 \mathrm{~cm}$. Two cores $(d=5 \mathrm{~cm})$ were taken from the center and two from the edge, about $90^{\circ}$ apart.

Upon visual examination of the cores, it was apparent that although the waste was coated with binder, the layers of compasted waste were not sufficiently laminated together to form a solid monolith. This may be due to the large number of voids in the waste form, to excessive draining of binder from the waste form prior to polymerization, or the inhornogeneity of the waste. This demonstrates the desirability of 
shredding prior to compaction to improve overall homogeneity, and the importance of compaction at higher pressures to eliminate the voids, minimize binder requirements and to produce an improved waste form. 


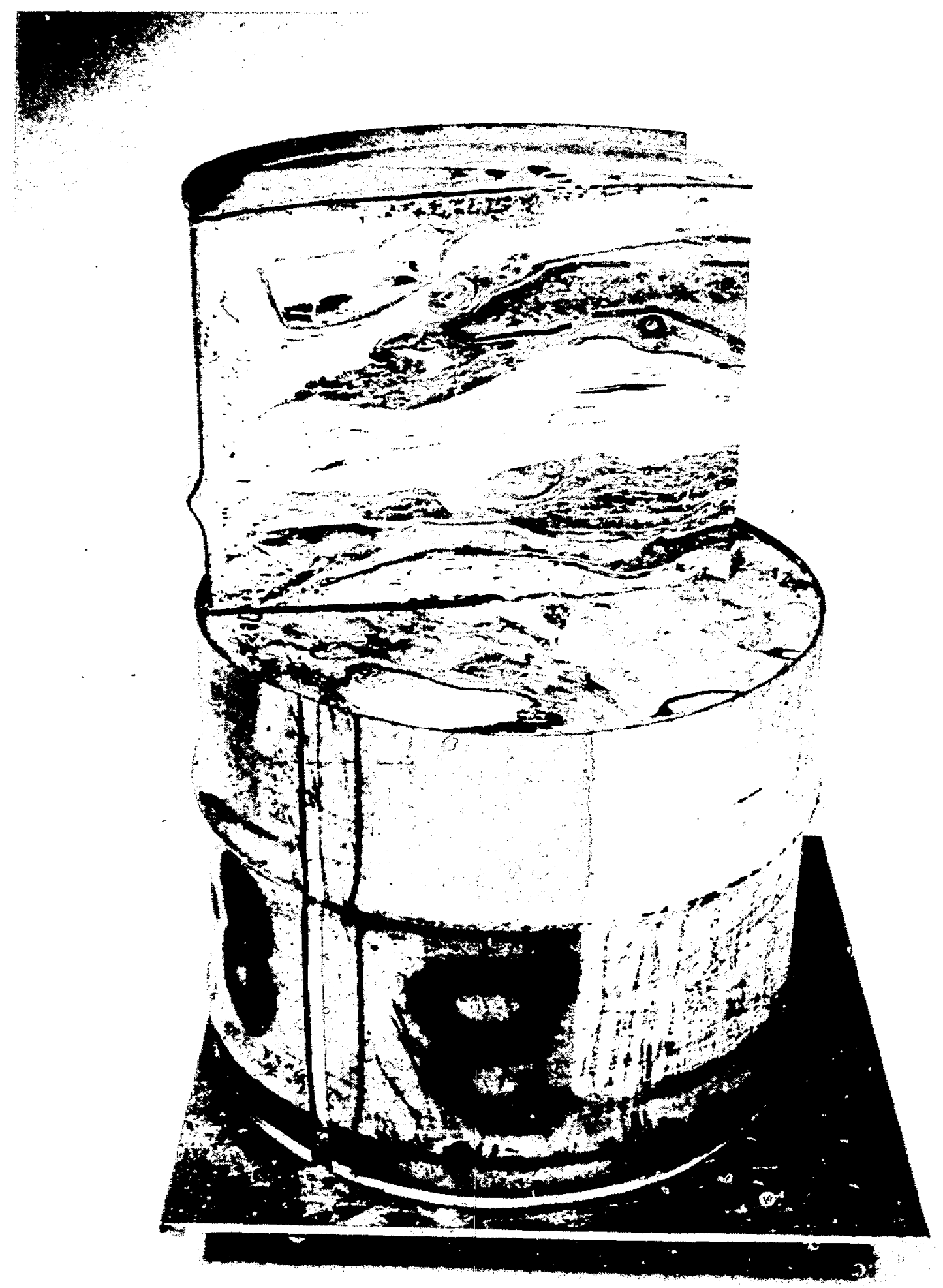

Figure 5.4 Cross-sections of a stabilized 55-gallon drum waste form. 


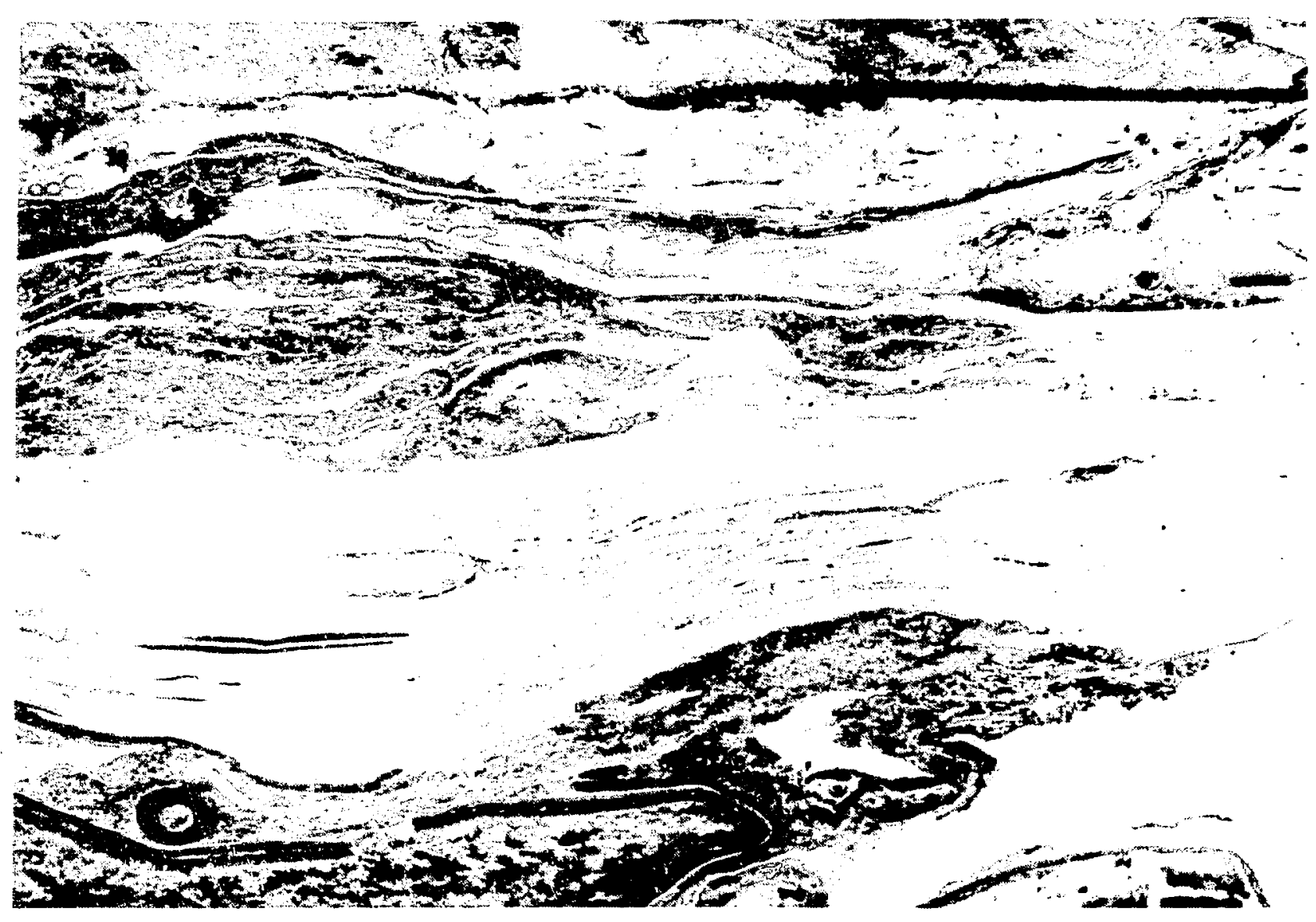

Figure 5.5 A close-up view of a stabilized full-scale waste form.

Table 5.1

Compressive Strengths of Samples from Stabilized

Full-Scale Compacted Waste Form

Compressive Strength (psi)

\begin{tabular}{ccc} 
Sample & Control & After (90 days) Immersion \\
\cline { 2 - 3 } & 430 & 610 \\
B & 720 & 640 \\
C & 240 & 220
\end{tabular}




\section{REFERENCES}

1. P. Kalb and P. Colombo, Identification of DOE Low-Level Radioactive Problem Wastes, Letter Report, BNL-36820, Brookhaven National Laboratory, Upton, NY, August 1985 (Revised).

2. E.M. Franz, John H. Heiser, III and P. Colombo, Solidification of Problem Wastes, Annual Progress Report, BNL-52078, Brookhaven National Laboratory, Upton, NY, February 1987.

3. E.M. Franz and P. Colombo, Waste Form Evaluation Program, Finai Report, BNL-51954, Brookhaven National Laboratory, Upton, NY, September 1985.

4. E.M. Franz, J.H. Heiser, III, and P. Colombo, Immobilization of Sodium Nitrate Waste with Polymers, Topical Report, BNL-52081, Brookhaven National Laboratory, Upton, NY, April 198 ?

5. Hazardous Waste Remedial Action Program, Annual Progress Report for the period ending September 30, 1989, DOE/HWP-102, (in press).

6. M. Steinberg and P. Colombo, Preliminary Survey of Polymer Impregnated Stone, BNL-52055, Brookhaven National Laboratory, Upton, New York, September 1970.

7. M. Steinberg, P. Colombo, and L.E. Kukacka, assignors to USAEC Method of Producing Plastic impregnated Concrete, U.S. Patent 3,567,496, March 2, 1971.

8. U.S. Nuclear Regulatory Commission, "Technical Branch Position on Waste Forms," Final Waste Classification and Waste Form Technical Position Papers, U.S. Nuclear Regulatory Commission, Washington, D.C., May 1983.

9. U.S. Nuclear Regulatory Commission, "Licensing Requirements for Land Disposal of Radioactive Waste," Title 10 of the Code of Federal Regulations, Part 61, U.S. Nuclear Regulatory Commission, Washington, D.C., May 1983. 